\title{
Assessment of Keratinase and Other Hydrolytic Enzymes in Thermophilic Bacteria Isolated from Geothermal Areas in Patagonia Argentina
}

\author{
I. Cavello ${ }^{a}$, M. S. Urbieta ${ }^{a}$, A. B. Segretin ${ }^{a}$, A. Giaveno ${ }^{b}$, S. Cavalitto ${ }^{a}$, and E. R. Donati ${ }^{a}$

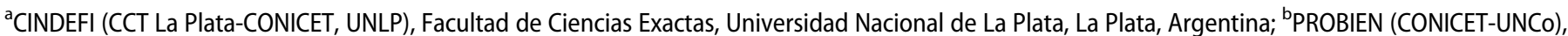 \\ Laboratorio de Biolixiviación, Departamento de Química - Facultad de Ingeniería, Universidad Nacional del Comahue, Neuquén, Argentina
}

\begin{abstract}
Thermophilic aerobic bacteria were isolated from two geothermal areas in Neuquén province using two different enrichment methods and a total of 30 isolates were obtained. From chicken feather enrichment cultures, strains affiliated to Bacillus cytotoxicus and Bacillus licheniformis were isolated and all of them demonstrated the capability to degrade completely chicken feather. A preliminary research on biotechnological enzymes' potential demonstrated that all the isolates displayed at least one of the extracellular hydrolytic enzymes tested. Most of the isolates showed protease, inulinase and/or pectinase activities, while cellulase and xylanase activities were less common. In light of these findings, geothermal areas of Argentina may be considered as a potential source of thermophilic bacteria able to produce many industrially relevant enzymes.
\end{abstract}

\section{ARTICLE HISTORY}

Received 29 April 2017

Accepted 2 June 2017

\section{KEYWORDS}

Biodiversity; keratinolytic microorganisms;

thermophilic bacteria

\section{Introduction}

The enzymes produced by microorganisms that live in extreme environments are considered versatile tools for the development and improvement of a variety of industrial and biotechnological processes due to their stability under extreme and non-conventional conditions, the reduction of contamination risks, the improved use of raw materials and decrease of waste products' generation in comparison with enzymes obtained from mesophiles (Loperena et al. 2012; Margesin et al. 2009).

Examples of extremozymes include cellulases, pectinases, amylases, xylanases, proteases, lipases, keratinases and cellulases which have great potential for applications in various biotechnological processes. Currently, only $1-2 \%$ of microorganisms on the Earth have been commercially exploited and among these, there are only a few examples of extremophiles (Vieille and Zeikus 2001). The detergent, food, feed, starch, textile, leather, pulp and pharmaceutical industries are the major users of these kinds of enzymes (Haki and Rakshit 2003).

As previously mentioned, extreme environments are a suitable niche for microorganisms that might produce enzymes which are able to fulfill the needs of modern industrial processes. In that sense, Patagonia Argentina presents many geothermal areas inhabited by extremophilic microorganisms (Urbieta et al. 2014). Copahue and Domuyo are two geothermal areas located in the northwest corner of Neuquén province in Cordillera de los Andes (Argentina) (Supplementary Figure 1). Copahue geothermal area is under the influence of the Copahue volcano [2900 m above sea level (m.a.s.l)], a stratovolcano still active. Due to its constant activity, the area presents various ponds, pools, and hot springs with a wide range of temperatures in various manifestations (from $10^{\circ} \mathrm{C}$ to approximately $90^{\circ} \mathrm{C}$, close to the boiling point of water at Copahue's altitude). It is chiefly an acidic environment with $\mathrm{pH}$ values between 2.0 and 4.0; however, neutral microenvironments, especially in sediments and biofilms, can be found (Vallés et al. 2004; Varekamp et al. 2009). Domuyo geothermal area is emplaced in the southern slope of the Domuyo hill, the highest peck in Patagonia with an elevation of 4.709 m.a.s.l. Domuyo is not a stratovolcano; however, there are magmatic chambers near the base of the hill that control the geothermal activity of the area (Pesce 2013). There, the surface manifestations that include fumaroles, hot springs, and geysers are mostly of neutral $\mathrm{pH}$ and high temperatures.

Around the world, biodiversity and bioprospection of thermophilic microorganisms are topics of great interest (Arya et al. 2015; Baltaci et al. 2017; Kublanov et al. 2009). However, in Argentina - especially in relation to Copahue and Domuyo geothermal areas - only the microbial biodiversity of the acidic ponds and biofilms in the Copahue geothermal field has been studied (Chiacchiarini et al. 2010; Urbieta et al. 2014; Urbieta et al. 2015).

This work represents the first study on the isolation, identification and characterization of thermophilic bacteria from neutral extreme environments of Copahue and Domuyo pristine geothermal areas.

The isolation of keratinolytic bacteria was prioritized due its interesting potential. It is widely known that a large number of mesophilic keratinolytic microorganisms have been studied (Riffel et al. 2003; Sangali and Brandelli 2000) and some of them can even produce keratinases that are active at higher 


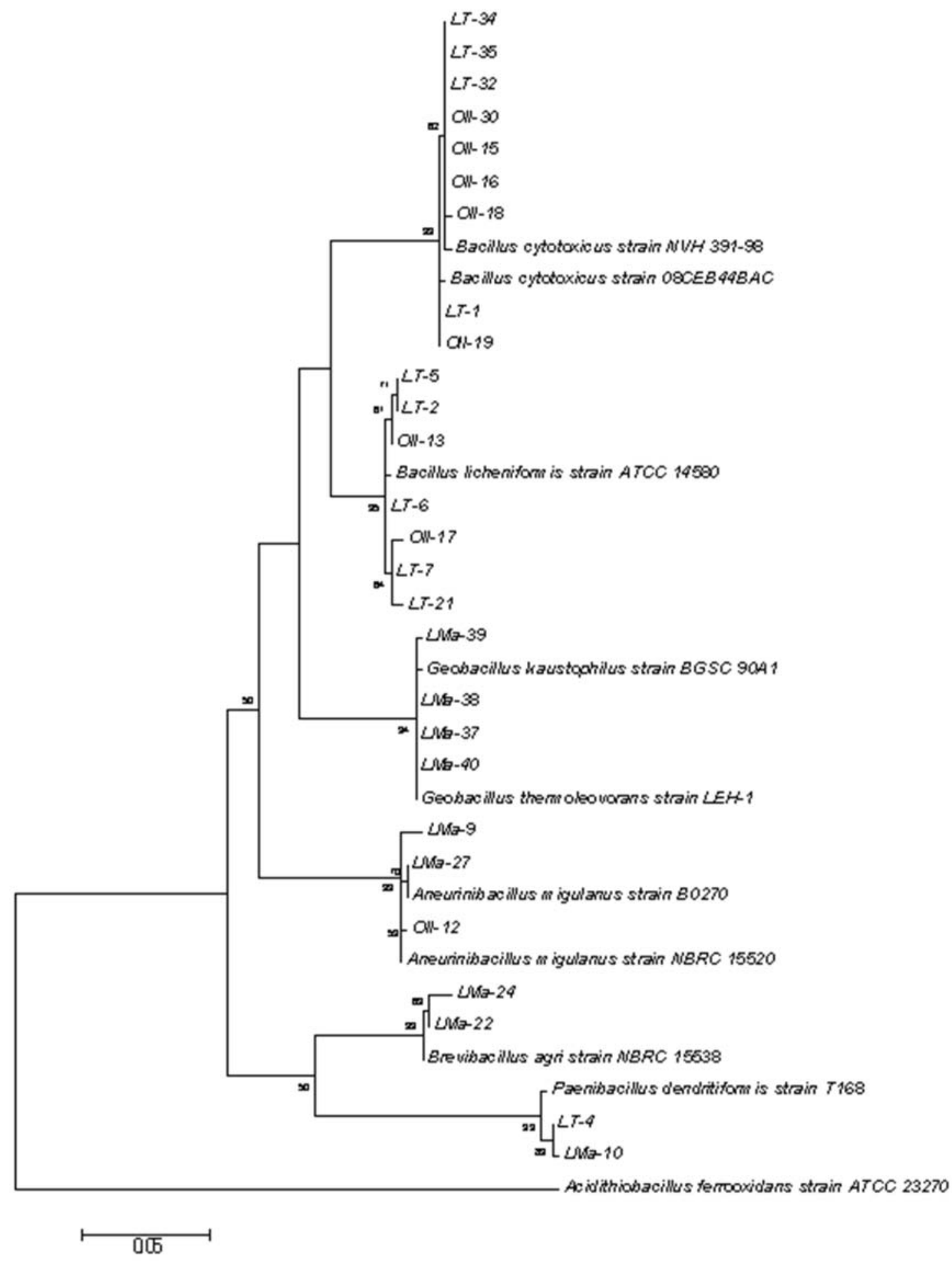

Figure 1. Molecular phylogenetic analysis by the Maximum Likelihood method. Bootstrap values are given at each branch point. Acidithiobacillus ferrooxidans was used as an out-group to root the tree. Bar, 0.05 substitutions per site. Only bootstrap values $>50 \%$ are shown at nodes.

temperatures (De Toni et al. 2002; Lin et al. 1992). Till today, only few thermophilic keratinolytic bacteria are known, for instance Fervidobacterium pennivorans (Friedrich and Antranikian 1996), Fervidobacterium islandicum AW-1 (Nam et al. 2002), Thermoanaerobacter keratinophilus 2KXI (Riessen and Antranikian 2001), Caldanaerobacter sp. strain 1523-1 (Kublanov et al. 2009), Clostridium sporogenes bv. pennavorans (Ionata et al. 2008), and Meiothermus ruber H328 (Matsui et al. 2009), all of them being anaerobic microorganisms.
In recent years, the demand for thermostable keratinolytic enzymes by a number of industries has increased and there is still a need to find more robust and specific thermostable keratinolytic enzymes which reveal an interesting field to explore. These enzymes have demonstrated to have several application fields and can be applied to detergent, leather, textile, food, and pharmaceutical industries (Gupta et al. 2013a).

In this work, samples coming from two geothermal areas were studied using two different enrichment techniques. With 
the aim to isolate keratinolytic bacteria, a chicken feather medium was used. Nutrient Broth (NB) was used to isolate those microorganisms that could not grow on the chicken feather medium but could display an interesting enzyme activity profile. We focused our attention not only on keratinase activity but also on protease, esterase, inulinase, pectinase, cellulase and xylanase activities.

\section{Materials and methods}

\section{Sample collection}

Sediments, water, and biofilms were aseptically collected from the manifestations Las Olletas $\left(37^{\circ} 8^{\prime} 3.7036^{\prime \prime} \mathrm{S}, 70^{\circ} 14^{\prime} 26.9970^{\prime \prime}\right.$ $\mathrm{W})$ and Los Tachos ( $\left.36^{\circ} 39^{\prime} 32.4200^{\prime \prime} \mathrm{S}, 70^{\circ} 35^{\prime} 2.7200^{\prime \prime} \mathrm{W}\right)$ in Domuyo and from Las Máquinas $\left(37^{\circ} 49^{\prime} 11.8000^{\prime \prime} \mathrm{S}, 71^{\circ} 05^{\prime}\right.$ $16.6000^{\prime \prime} \mathrm{W}$ ) in Copahue and kept at room temperature until processed for incubation and isolation. Temperature and $\mathrm{pH}$ were measured in situ with a Hanna HI 8424 NEW portable instrument properly calibrated against calibration standards. The main characteristics of the samples collected are listed in Table 1.

Las Olletas is located on the top of the valley of the Manchana Covunco stream and it is a thermal manifestation dominated by high-temperature water and sodium chloride (Mas et al. 1996). Los Tachos is located on the valley of the Cavunco stream; it is a wide, high-temperature hot spring of water vapor mixed type with sodium chloride as its major component (Mas et al. 1996).

Las Máquinas is $2.2 \mathrm{~km}$ away from Copahue village and it is the less human intervened of the five manifestations found in the Copahue geothermal system. The waters in the ponds, fumaroles, and hot springs are rich in sulfate and on the walls, small sulfur and pyrite crystals can be found (Supplementary Figure 2 shows images of the three sampling locations and supplementary Table 1 shows the water chemistry of the collection sites).

\section{Isolation of microorganisms}

Approximately $1 \mathrm{~g}$ of each environmental sample collected from Los Tachos, Las Olletas, and Las Máquinas was inoculated in 500-ml Erlenmeyer flasks containing $100 \mathrm{ml}$ of NB (Britania, $\mathrm{pH}$ 7.0). Cultures coming from samples 1 to 6 were incubated at $50^{\circ} \mathrm{C}$, while cultures coming from sample 7 were inoculated in two separate Erlenmeyer flasks and incubated at $50^{\circ} \mathrm{C}$ and $65^{\circ} \mathrm{C}$, respectively. These enrichment cultures were incubated for $24 \mathrm{~h}$ in an orbital shaker at $150 \mathrm{rpm}$ and then, $0.1 \mathrm{ml}$ (and $1 / 10$ and $1 / 100$ dilutions) of the cultures was spread in nutrient agar (NA) plates solidified with $2 \%$ agar or $0.75 \%$ gelrite (Sigma, for plates incubated at $65^{\circ} \mathrm{C}$ ) and incubated at $50^{\circ} \mathrm{C}$ or $65^{\circ} \mathrm{C}$. Single colonies were streaked twice on NA plates to obtain microbial monoculture.

In addition, in order to isolate keratinolytic bacteria, an enrichment step using a keratin substrate was performed:

Approximately $1 \mathrm{~g}$ of each environmental sample was inoculated in 500-ml Erlenmeyer flasks containing $50 \mathrm{ml}$ of mineral media (described later) supplemented with whole chicken feather as the sole carbon and nitrogen sources. Cultures were incubated following the same procedure described previously until feather degradation was confirmed visually (1-5 days). For the isolation of the keratinolytic microorganisms, $0.1 \mathrm{ml}$ (and 1/10 and 1/100 dilutions) of the cultures was spread in NA plates. Single colonies were streaked twice on NA agar plates to obtain microbial monoculture.

Isolates were stored in $\mathrm{NB}$ with $15 \%$ glycerol at $-80^{\circ} \mathrm{C}$.

The formulation of the mineral media $\left(1^{-1}\right)$ is as follows: chicken feathers $10 \mathrm{~g} ; \mathrm{NaH}_{2} \mathrm{PO}_{4} 0.496 \mathrm{~g} ; \mathrm{K}_{2} \mathrm{HPO}_{4} 2.486 \mathrm{~g}$ and $0.50 \mathrm{ml}$ of trace elements' solution $\left(\mathrm{FeCl}_{3} \cdot 6 \mathrm{H}_{2} \mathrm{O} 0.016 \mathrm{~g} ; \mathrm{ZnCl}_{2}\right.$ $0.013 \mathrm{~g} \mathrm{MgCl}_{2}, 0.010 \mathrm{~g}$ and $\mathrm{CaCl}_{2} 0.00011 \mathrm{~g}$ ) adjusted at $\mathrm{pH} 7.0$ (Cavello et al. 2012). The chicken feathers were supplied by a local slaughterhouse; they were washed thoroughly with $0.1 \%$ $(\mathrm{w} / \mathrm{v})$ sodium dodecil sulfate to remove surface contaminants, then with $1: 1(\mathrm{v} / \mathrm{v})$ methanol:water by shaking for $18 \mathrm{~h}$ at $28^{\circ} \mathrm{C}$; afterward, they were rinsed with distilled water then with 95\% ethanol and finally air dried.

\section{Biochemical characterization of isolates}

Bacterial isolates were subjected to conventional tests such as indole, methyl red, and Voges-Proskauer, Simmons citrate, catalase and oxidase, nitrate reduction, gelatin hydrolysis, $\mathrm{H}_{2} \mathrm{~S}$ production, and carbohydrate fermentation (glucose and lactose) according to the methods described by Harley and Prescott (2002).

The $\mathrm{pH}$ and temperature range for bacterial growth were tested between $4.0-12.0$ and $20-65^{\circ} \mathrm{C}$, respectively.

Growth at different $\mathrm{NaCl}$ concentrations $(0-10 \%$ w/v) was tested on $\mathrm{NB}$ media at $\mathrm{pH}$ 7.0. Growth was monitored by turbidity at $\mathrm{OD}_{600 \mathrm{~nm}}$.

Table 1. Main characteristics of the samples collected for the isolation of heterotrophic microorganisms.

\begin{tabular}{|c|c|c|c|c|c|c|c|}
\hline \multirow[b]{2}{*}{$\begin{array}{l}\text { Sample } \\
\text { no. }\end{array}$} & \multirow[b]{2}{*}{ Location } & \multirow[b]{2}{*}{ Sample kind } & \multirow[b]{2}{*}{$\begin{array}{l}\text { Original } \\
\text { temperature }\left({ }^{\circ} \mathrm{C}\right)\end{array}$} & \multirow[b]{2}{*}{$\mathrm{pH}$} & \multicolumn{2}{|c|}{$\begin{array}{c}\text { No. of different morphotypes } \\
\text { observed after }\end{array}$} & \multirow[b]{2}{*}{ Strain name } \\
\hline & & & & & $\begin{array}{l}\text { Nutrient broth } \\
\text { enrichement }\end{array}$ & $\begin{array}{c}\text { Feather } \\
\text { enrichement }\end{array}$ & \\
\hline 1 & Las Olletas & Biofilm & $57-60$ & 7.0 & 2 & 1 & Oll-12, Oll-13 \\
\hline 2 & Las Olletas & Biofilm & $50-57$ & 7.0 & $1^{*}$ & $1^{*}$ & Oll-16, Oll-19, Oll-30 \\
\hline 3 & Los Tachos & Water & 57 & 7.0 & $1^{*}$ & $1^{*}$ & LT-6, LT-7, LT-8, LT-21 \\
\hline 4 & Las Olletas & Water & 57 & 7.0 & $2^{*}$ & $2^{*}$ & Oll-15, Oll-17, Oll-18 \\
\hline 5 & Las Máquinas & Biofilm & 50 & 7.0 & 5 & - & LMa-9, LMa-10, LMa-22, LMa-24, LMa-25 \\
\hline 6 & Los Tachos & Biofilm & 57 & 7.0 & 3 & 2 & LT-1, LT-2, LT-4, LT-5, LT-32, LT-34, LT-35 \\
\hline 7 & Las Máquinas & $\begin{array}{l}\text { Light red and } \\
\text { Light brown soil }\end{array}$ & 68.5 & 7.5 & $50^{\circ} \mathrm{C}(2) ; 65^{\circ} \mathrm{C}(4)$ & - & $\begin{array}{l}\text { LMa- 26, LMa-27, LMa-36, LMa-37, LMa- } \\
\text { 38, LMa-39, LMa-40 }\end{array}$ \\
\hline
\end{tabular}

The number of morphotypes observed after an enrichment step in nutrient broth or feather medium is also presented.

* Same morphology in both enrichment media was observed.

- Growth not detected. 


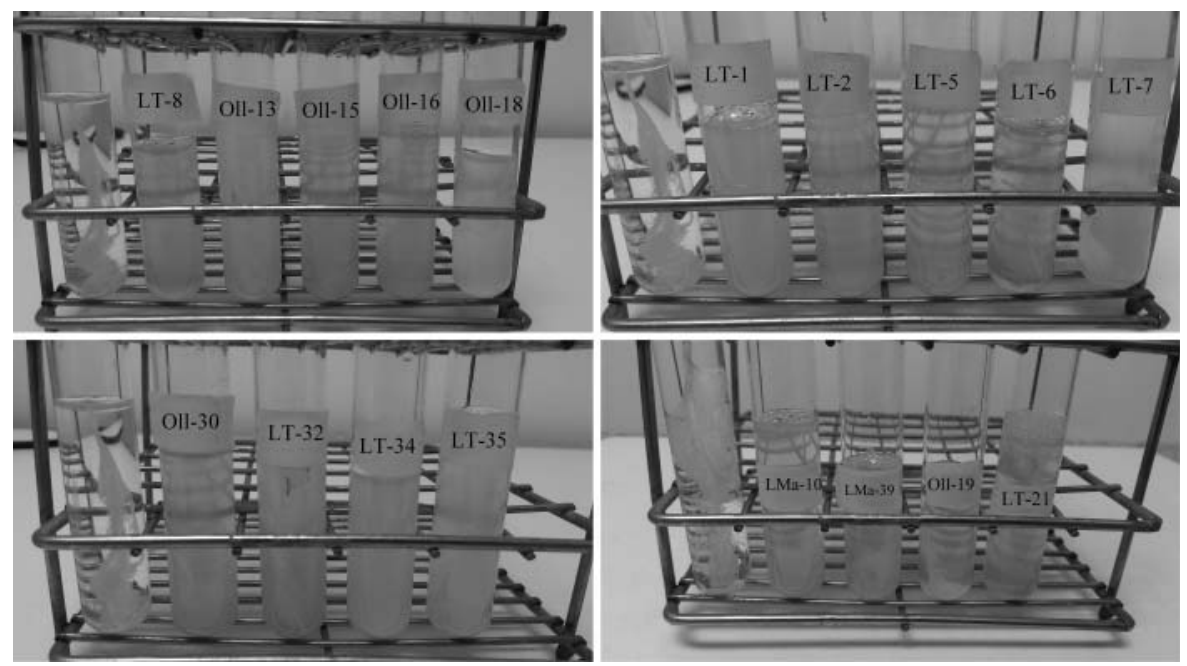

Figure 2. Feather-degrading potential of isolates. Cultivation was performed at $50^{\circ} \mathrm{C}$ or $65^{\circ} \mathrm{C}$ for $96 \mathrm{~h}$ and visually checked for feather degradation. Non-inoculated (left) control was incubated at the same conditions.

\section{DNA extraction, 16s rRNA gene amplification and phylogenetic characterization}

The genomic DNA of each isolate was extracted as described by Park (2007). The 16S rRNA gene of each isolate was amplified using the primers 27F: 5'- AGAGTTTGATCCTGGCTCAG $-3^{\prime}$ and 1541R: 5'- AAGGAGGTGATCCAGCCGCA-3'. PCR was performed according to Urbieta et al. (2014). PCR amplification was checked by $1.5 \%$ agarose gel electrophoresis stained with ethidium bromide. The 16S rRNA gene product of each isolate was sequenced using Macrogen services (Macrogen Inc, Seoul, South Korea). The respective sequences were analyzed and compared with NCBI database using BLASTn software (http://ncbi.nlm.nih.gov/BLAST). The 16S rRNA gene sequences of the isolates were deposited in NCBI data base under the accession numbers KR559937-KR559957.

A sequence comparison with the databases was performed using the BLAST program through the NCBI website. A phylogenetic tree was constructed using the Neighbor Joining method by using the software package MEGA version 6 (Tamura et al. 2013). The robustness of individual branches was estimated by bootstrapping with 1000 replicates. Acidithiobacillus ferrooxidans ATCC 23270 was used as the outside group.

\section{Screening of lytic enzymes production}

Seven lytic activities were tested on the isolates growing on solid media at $50^{\circ} \mathrm{C}$ or $65^{\circ} \mathrm{C}$, respectively, and the keratinolytic activity was studied on liquid media as described below.

\section{Determination of protease activity}

This activity was evaluated using a skim milk agar medium consisting of $\left(1^{-1}\right)$ skim milk $10 \mathrm{~g}$ and agar $20 \mathrm{~g}$ (pH 6.6). After incubation, a positive reaction was detected as a clear zone around the colony in the opaque medium (Kim et al. 2001).

\section{Determination of esterase activity}

The ability to degrade long-chain esters was detected using sorbitan monooleate (Tween 80, Sigma-Aldrich). Tween 80 medium agar consisted of $\left(\mathrm{l}^{-1}\right)$ peptone $10 \mathrm{~g} ; \mathrm{NaCl} 5 \mathrm{~g} ; \mathrm{CaCl}_{2} \cdot 2 \mathrm{H}_{2} \mathrm{O} 0.1 \mathrm{~g}$ and agar $20 \mathrm{~g}(\mathrm{pH} 7.0)$. The presence of esterase activity was seen as an opaque halo around the colony (Plou et al. 1998).

\section{Determination of pectinase activity}

It was evaluated using a selective medium containing $\left(1^{-1}\right)$ citric pectin (Sigma-Aldrich) $10 \mathrm{~g}$; yeast extract $2 \mathrm{~g}$; peptone $5 \mathrm{~g}$; $\left(\mathrm{NH}_{4}\right)_{2} \mathrm{SO}_{4} 1.4 \mathrm{~g} ; \mathrm{K}_{2} \mathrm{HPO}_{4} 2 \mathrm{~g} ; \mathrm{MgSO}_{4} \cdot 7 \mathrm{H}_{2} \mathrm{O} 0.2 \mathrm{~g} ; 1 \mathrm{ml}$ of solution $\mathrm{A}\left(\mathrm{FeSO}_{4} \cdot \mathrm{H}_{2} \mathrm{O} 0.005 \mathrm{~g} ; \mathrm{MnSO}_{4} \cdot \mathrm{H}_{2} \mathrm{O} 0.0016 \mathrm{~g} ; \mathrm{CoCl}_{2}\right.$ $0.002 \mathrm{~g}$ ) and $20 \mathrm{~g} \mathrm{l}^{-1}$ agar.

\section{Determination on inulinase activity}

It was detected using inulin agar media consisting of $\left(1^{-1}\right)$ inulin $10 \mathrm{~g}$; yeast extract $2 \mathrm{~g}$; peptone $5 \mathrm{~g} ; \mathrm{MgSO}_{4} 0.5 \mathrm{~g} ; \mathrm{NaCl} 0.5 \mathrm{~g}$; $\mathrm{CaCl}_{2} 0.15 \mathrm{~g}$ and agar $20 \mathrm{~g}$ (pH 6.0).

\section{Determination of amylase activity}

The ability to degrade starch was evaluated using starch agar, which consisted of $\left(1^{-1}\right)$ soluble starch (Mallinckrodt Baker Inc.) $10 \mathrm{~g}$; yeast extract $2 \mathrm{~g}$; peptone $5 \mathrm{~g}$; $\mathrm{MgSO}_{4} 0.5 \mathrm{~g}$; $\mathrm{NaCl}$ $0.5 \mathrm{~g} ; \mathrm{CaCl}_{2} 0.15 \mathrm{~g}$ and agar $20 \mathrm{~g}(\mathrm{pH} 6.0)$.

Colonies producing pectinases, inulinases or amylases were screened and selected by flooding the solid media plates with Lugol's iodine solution (Buzzini and Martini 2002).

\section{Determination of cellulase (CMCase) activity}

It was performed on a carboxymethylcellulose (CMC) agar medium containing $\left(\mathrm{l}^{-1}\right) \mathrm{NaNO}_{3} 2 \mathrm{~g} ; \mathrm{K}_{2} \mathrm{HPO}_{4} 1 \mathrm{~g} ; \mathrm{MgSO}_{4}$ $0.5 \mathrm{~g}$; $\mathrm{KCl} 0.5 \mathrm{~g}$; CMC sodium salt (Mallinckrodt Baker Inc.) $2 \mathrm{~g}$; peptone $0.2 \mathrm{~g}$ and agar $17 \mathrm{~g}$ ( $\mathrm{pH} 6.0)$.

\section{Determination of xylanase activity}

It was performed on an agar medium containing $\left(1^{-1}\right)$ xylan from Birchwood (Sigma-Aldrich) $10 \mathrm{~g}$; yeast extract $5 \mathrm{~g}$; peptone $5 \mathrm{~g} ; \mathrm{K}_{2} \mathrm{HPO}_{4} 1 \mathrm{~g} ; \mathrm{MgSO}_{4} \cdot 7 \mathrm{H}_{2} \mathrm{O} 0.2 \mathrm{~g}$ and agar $20 \mathrm{~g}$.

Cellulase and xylanase producing colonies were screened and selected by flooding the solid media plates with Congo Red solution $(0.1 \%)$ and distained with $\mathrm{NaCl} 1 \mathrm{M}$ (Rohban et al. 2009). 
In all the determination, the plates were incubated for 3 days in a humidity chamber. In case the isolates were incubated at $65^{\circ} \mathrm{C}$, agar was replaced by gelrite $(0.75 \mathrm{w} / \mathrm{v} \%)$.

\section{Qualitative evaluation of feather degradation - keratinolytic potential}

Proteolytic bacteria isolates coming from NB and from chicken feather enrichment were evaluated for feather degrading potential on test tubes containing $10 \mathrm{ml}$ of Mineral Media (MM) and a single chicken feather. After inoculation of each bacterial isolate, the tubes were incubated for up to 5 days at $50^{\circ} \mathrm{C}$ (or $65^{\circ} \mathrm{C}$ ) and $150 \mathrm{rpm}$ being checked daily.

\section{Results}

\section{Bacteria isolation}

Bacterial colonies obtained either from NB and from chicken feather enrichment were examined macro- and microscopically and those showing different morphotypes were selected from each sample and purified by streaking them on NA. From these enrichment cultures, a collection of 30 heterotrophic thermophilic isolates was obtained, comprising 18 isolates from NB enrichment and 13 isolates from feather medium enrichment, respectively (Table 1). A large number of microorganisms with different colony formations and cell morphologies could be isolated from samples from Los Tachos (Domuyo) and Las Máquinas (Copahue), while from samples from La Olletas (Domuyo), one or two different morphotypes could be observed (Table 1).

When the morphotypes of the colonies were similar, the selection was done prioritizing those obtained after feather enrichment. It could be seen that no growth was detected when feather enrichment was performed using samples 5 and 7 from La Máquinas geothermal areas.

The microorganisms isolated were subjected to conventional tests to characterize them, and the results are summarized in Supplementary Table 2.

The growth ranges for $\mathrm{pH}$ and temperature were determined as $5.0-9.0$ and $50-65^{\circ} \mathrm{C}$, except for 10 isolates (LT-1, LT-32, LT-33, LT-34, LT-35, Oll-15, Oll-16, Oll-18, Oll-19 and Oll-30) where the range of temperature during their growth was $20-50^{\circ} \mathrm{C}$.

Concerning the growth in the NB medium supplemented with $\mathrm{NaCl}$, all the isolates - except LMa-37 - were able to grow in the presence of $\mathrm{NaCl}$. Fifteen of the isolates were able to grow in a wide range of salt concentrations and could be considered not only thermophiles but also moderate halophiles (Table 2).

\section{Identification of the isolates}

The isolates were identified by sequencing the almost complete 16S rRNA gene (Table 3). All of them were related to the class Bacilli and five different genera were identified (Bacillus, Paenibacillus, Aneurinibacillus, Brevibacillus, and Geobacillus), with Bacillus representing the largest proportion of isolates (17 out of 30 isolates) (Table 3). The isolates associated with the genus Bacillus were obtained only from samples collected at the manifestations Las Olletas and Los Tachos in the Domuyo geothermal area, while the isolates associated with the genera Brevibacillus and Geobacillus were only isolated from samples from Las Máquinas geothermal areas. Paenibacillus and Aneurinibacillus species were isolated from both sampling locations in Copahue and Domuyo.

Eight isolates (LT-1, LT-32, LT-34, LT-35, Oll-15, Oll-16, Oll-18, and Oll-30) showed $99 \%$ similarity to Bacillus cytotoxicus and eight (LT-2, LT-5, LT-6, LT-7, LT-8, LT-21, Oll-13 and Oll-17) were related to Bacillus licheniformis with $99 \%$ similarity. All these isolates came from samples of Los Tachos and Las Olletas in the Domuyo geothermal area.

Isolate LMa 39 shared $98 \%$ of the sequence similarity with Geobacillus kaustophilus, while the isolates LMa-37, LMa 38 and LMa 40 showed the same identity percentage to more than one species of the genus Geobacillus (G. kaustophilus, G. thermoleovorans and G. thermoparaffinivorans) and were named as Geobacillus sp.

The phylogenetic tree based on the 16S rRNA gene is shown in Figure 1.

\section{Enzymatic evaluation of all isolates}

In order to evaluate the potentiality of the thermophilic isolates, we tested for eight different hydrolytic enzymatic activities of industrial relevance. Both the isolation scheme and the screening process lead us toward selecting the most promising microorganisms for future extreme environment biotechnological processes.

Protease activity was produced by $83 \%(\mathrm{n}=25)$ of the isolates, followed by keratinase, inulinase and pectinase activities that were evidenced by $53 \%, 43 \%$ and $43 \%$ of the isolates, respectively. Amylase activity was presented in $40 \%(n=12)$ of the isolates, while esterase activity was produced by $23 \%(n=7)$ of them. Cellulase activity was detected in $20 \%$ of the isolates. The enzymatic activity less produced by the isolates was xylanases, with only $7 \%$ of the positive results $(n=2)$ (Table 2$)$.

When considering the phylogenetic distribution of the enzymatic activities, we found that proteolytic activity was produced by members of all the genera. All the isolates coming from feather medium enrichment showed proteolytic activity and, 12 from 18 of the isolates coming from NB enrichment also displayed this activity. When these proteolytic bacteria were subjected to qualitative evaluation of feather degradation, $100 \%$ of those coming from feather medium enrichment were able to completely degrade entire feather (LT-1, LT-2, LT-6-LT8, Oll-13, Oll-15, Oll-16, Oll-18, Oll-30, LT-32, LT-34 and LT-35) and they were affiliated to B. cytotoxicus and B. licheniformis species (Figure 2). Meanwhile, only three of the 12 proteolytic bacteria coming from NB enrichment were capable to degrade whole chicken feather after 5 days and they were affiliated to B. licheniformis (LT-5), Paenibacillus dendritiformis (LMa-10) and Geobacillus sp. (LMa-39). The last isolate displayed keratinase activity only at $65^{\circ} \mathrm{C}$ and the degradation of chicken feather was not complete after 5 days of incubation.

Esterase and cellulase activities were less frequently found, the cellulase activity being detected in members of Paenibacillus, Brevibacillus and Aneurinibacillus but not in members of 


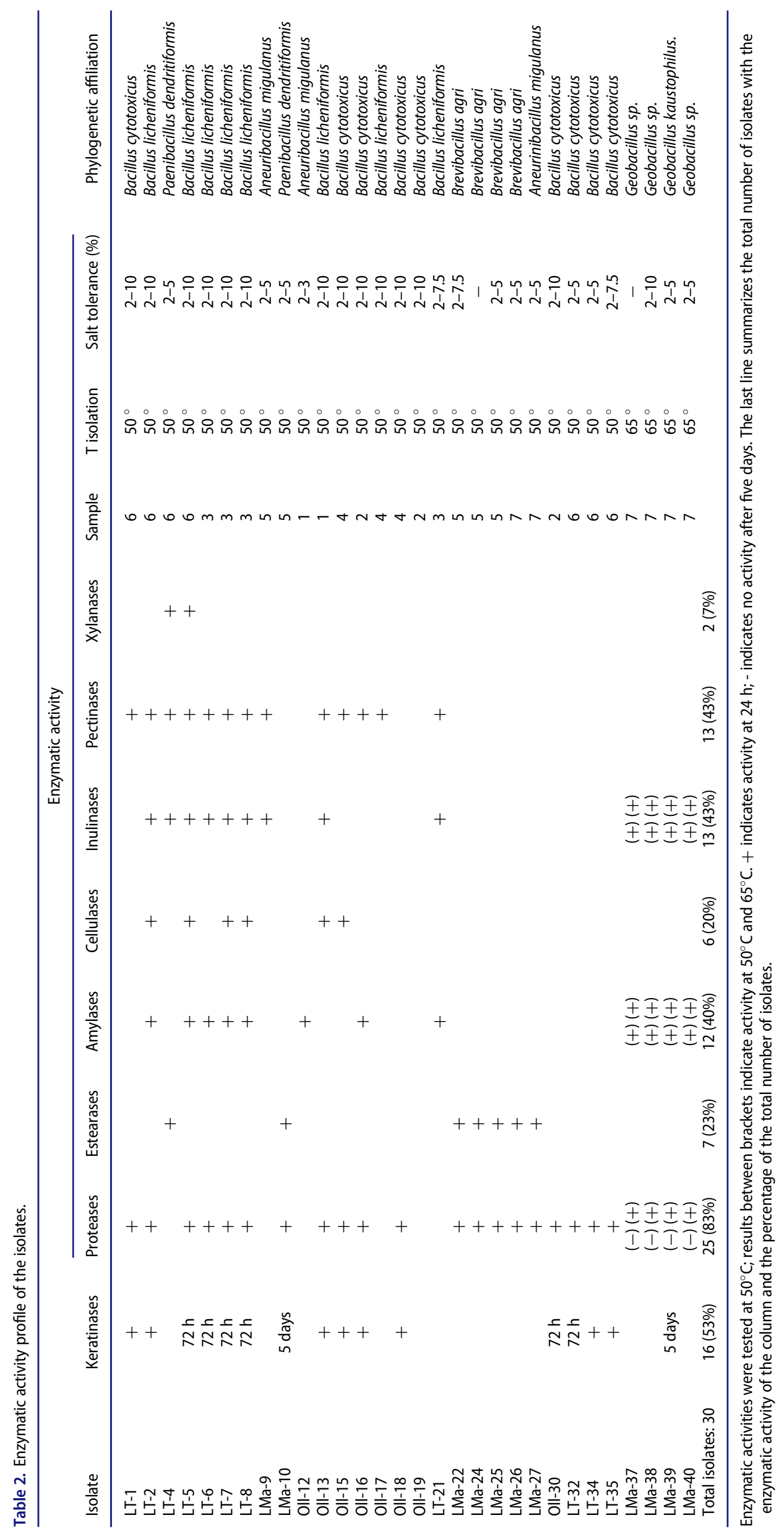


Table 3. Phylogenetic identification of the isolates.

\begin{tabular}{|c|c|c|c|}
\hline Isolate code & BLAST hit (closest phylogenetic relative) & GenBank accession $\mathrm{N}^{\circ}$ & Identity \% \\
\hline LT-2, LT-5, LT-6, LT-7, LT-8, LT-21, Oll-13, Oll-17 & Bacillus licheniformis & NR074923 & 99 \\
\hline LMa-9, OII-12, LMa-27 & Aneurinibacillus migulanus & NR113764 & 99 \\
\hline LMa-22, LMa-24, LMa-25, LMa-26 & Brevibacillus agri & KP284437 & 99 \\
\hline LMa 36, LMa-37, LMa38, LMa-39, LMa-40 & $\begin{array}{c}\text { Geobacillus kaustophilus, G. thermoleovorans, } \\
\text { G. thermoparaffinivorans }\end{array}$ & $\begin{array}{l}\text { KC252984, AY608939, } \\
\text { KC252973 }\end{array}$ & $99-98$ \\
\hline
\end{tabular}

Comparison of the $16 \mathrm{~S}$ rRNA gene sequences of the isolates with the $16 \mathrm{~S}$ rRNA gene sequences in the GenBank.

*The percentage identity with the 16SrRNA sequence of the closest phylogenetic relative.

the genus Bacillus and vice versa, and the ability to degrade CMC was detected only in members of genus Bacillus.

Xylan from Birchwood resulted in the hydrolysis only by two microorganisms, members of genera Bacillus (LT-5) and Paenibacillus (LT-4).

Interestingly, LT-5 affiliated with $B$. licheniformis showed the broadest spectrum of hydrolytic enzymes activities with seven out of the eight tested, including keratinase activity, followed by LT-2, LT-7, and LT-8 also affiliated with $B$. licheniformis, with six positive enzymatic activities, and LT- 6 and Oll-13 displaying five of the eight enzymes tested, respectively (Table 2).

All the isolates from Domuyo and Copahue geothermal areas were able to produce at least two extracellular enzymes.

\section{Discussion}

The growing interest in thermophilic microorganisms and their potential biotechnological applications explains the increasing number of studies in extremophilic microorganisms around the world (Aanniz et al. 2015; Adiguzel et al. 2009; Arya et al. 2015; Baltaci et al. 2017; Kublanov et al. 2009). The order Bacillales includes thermophilic members of the genera Geobacillus, Alicyclobacillus, Aneurinibacillus, Anoxybacillus, Bacillus, Brevibacillus, Caldalkalibacillus, Sulfobacillus, Thermobacillus, Ureibacillus and Vulcanibacillus and is responsible for the degradation of organic matter in hot environments (Logan and Allan 2008; Thebti et al. 2016).

In this work, we present a collection of 30 thermophilic bacteria isolated from the geothermal areas of Copahue and Domuyo in Neuquén province in Argentina using two enrichment methods; the first one performed in NB media allowed us to isolate microorganisms related to the genera Geobacillus, Aneuribacillus, Bacillus, Brevibacillus and Paenibacillus. From the feather medium enrichment, only microorganisms from genera Bacillus were recovered and they were classified as B. licheniformis and B. cytotoxicus. The keratinolytic microorganisms isolated from the enrichment in the feather medium presented a higher hydrolysis rate $(24-48 \mathrm{~h})$ than those isolated from NB confirming the importance of performing this kind of enrichment when the intention is to isolate microorganisms with certain metabolic or physiological characteristics.

In the literature, there are several works concerning to the isolation and characterization of thermophilic bacteria from different geothermal areas around the world. Some thermophilic species are commonly found, for example, B. licheniformis has been isolated over the last years from geothermal areas in Turkey (Baltaci et al. 2017), from Moroccan hot springs (Aanniz et al. 2015), from north Himalayan region (Verma et al. 2014) and now in Patagonia. Something similar occurs in relation to species belonging to the genera Geobacillus, Aneuribacillus and Brevibacillus (Acharya and Chaudhary 2012; Arya et al. 2015; Verma et al. 2014).

On the other hand, reports dealing with thermophilic microorganisms with the ability to degrade native feathers are scarce. F. pennivorans (Friedrich and Antranikian 1996), F. islandicum AW-1(Nam et al. 2002), T. keratinophilus 2KXI (Riessen and Antranikian 2001) and Caldanaerobacter sp. strain 1523-1 (Friedrich and Antranikian 1996; Kublanov et al. 2009; Nam et al. 2002; Riessen and Antranikian 2001), isolated from extreme environments such as hot springs, geothermal vents and volcanic areas, exhibited this ability; however, they required anaerobic growth conditions which hinder their practical utilization. An anaerobic thermotolerant bacterium, C. sporogenes bv. pennivorans, isolated from a solfataric mud $\left(35-40^{\circ} \mathrm{C}\right)$, showed that keratinolytic activity was reported by Ionata et al. (2008). Among moderately thermophilic aerobic bacteria $\left(50-60^{\circ} \mathrm{C}\right)$, the keratinolytic microorganisms reported are B. licheniformis PWD-1 (Williams et al. 1990), Streptomyces thermonitrificans MG104 (Mohamedin 1999), Bacillus subtilis RM-01 (Rai et al. 2009), Brevibacillus thermoruber T1E (Bihari et al. 2010) and Bacillus halodurans JB99 (Shrinivas and Naik 2011). M. ruber $\mathrm{H} 328$ is the only one that has been isolated from a hot spring, while all the other aerobic bacteria reported until now have been isolated from samples of soil, waste streams, sugarcane molasses and poultry wastes.

In relation to $B$. cytotoxicus, the natural habitat of this microorganism has not been determined yet and the majority of the strains described so far were isolated from vegetable products and related to food poisoning (Fagerlund et al. 2007; Guinebretiere et al. 2006; Guinebretiere et al. 2013; Lund et al. 2000).

Yeast diversity in Norwest Patagonia and their enzymatic profiles have been extensively studied (Brandao et al. 2011; Buzzini et al. 2012; Carrasco et al. 2012; Duarte et al. 2013; Mestre et al. 2011; Zalar and Gunde-Cimerman 2014). However, only studies dealing with yeast diversity of Rio Agrio and Lake Caviahue aquatic system (Russo et al. 2008) and microbial biodiversity of the acidic ponds and biofilms in the Copahue geothermal field have been published (Chiacchiarini et al. 2010; Urbieta et al. 2014; Urbieta et al. 2015) but no studies from Domuyo have been performed until now.

The current work reveals the potential of the thermophilic microorganisms isolated from Copahue and Domuyo geothermal areas to produce a wide range of hydrolytic enzymes. For 
instance, around $40 \%$ of the isolates demonstrated the ability to hydrolyze starch and inulin. The starch industry is one of the largest users of enzymes for the hydrolysis and modification of such useful raw material, representing $30 \%$ of the world's enzyme consumption (van der Maarel et al. 2002). The gelatinization of the starch granules is the first step of the enzymatic conversion and it is achieved by heating starch with water. The hydrolysis of starch has to proceed immediately after gelatinization; hence, in order to avoid high energy and time consumption for cooling, it is desirable that the amylases used are not only thermostable but also thermoactive. Although raw starch is very common in nature, there are few enzymes that can efficiently catalyze its hydrolysis (Hamilton et al. 1999). Saccharification of liquefied starch is carried out at low $\mathrm{pH}$ values and the amylases reported so far are not stable under such conditions. Inulinases have important industrial applications such as the production of pure fructose (inulin yields up to $95 \%$ pure fructose in a single-step enzymatic reaction), ethanol, gluconic acid, sorbitol, pullulan, and acetone-butanol (Gill et al. 2006). To obtain a high hydrolysis rate, the industrial process for the production of fructose from inulin needs to be performed at $60^{\circ} \mathrm{C}$; however, most of the inulinases reportedly lose their activity after a few hours at this temperature. Thus, there is an increasing interest in isolating and characterizing thermostable inulinases.

Cellulase activity was observed in $19 \%$ of the isolates. These enzymes are employed in the color extraction juices, in detergents causing color brightening and softening, in the biostoning of jeans, in the pre-treatment of biomass that contains cellulose to improve nutritional quality of forage and in the pre-treatment of industrial wastes (Nakamura et al. 2001).

The least common enzymatic activity found among the isolates was xylanase activity, which is present only in $P$. dendritiformis LT-4 and B. licheniformis LT-5. Xylan, the dominating component of hemicelluloses, has a vast application in pulp and paper industries. Pulp from wood is produced at high temperature and basic $\mathrm{pH}$, which implies that the enzymatic process requires xylanases with high thermostability and is active at broad pH range (Jacques et al. 2000). The pulp and paper are one of the fastest growing industries and the use of thermostable xylanases seems attractive since they offer a major step in the reduction of chlorine consumption in the bleaching process of Kraft pulp.

Proteases constitute $60 \%$ of the global enzyme market and have a wide area of applications, i.e., sectors such as detergents, leather, food, cosmetics, medicine, etc. (Gupta et al. 2013b). A special group of proteolytic microorganisms are those that are able to degrade the recalcitrant protein keratin. The thermophilic keratinolytic microorganisms reported in this work (52\% of the isolates) are potentially profitable candidates to be used in feather waste degradation considering that this waste is much more susceptible to degradation at high temperatures. In addition, fermentation processes at $50-55^{\circ} \mathrm{C}$ would be more suitable for sanitary demands due to the potential presence of avian influenza virus $\mathrm{H} 5 \mathrm{~N} 1$ which is known to lose its viability above $50^{\circ} \mathrm{C}$ (De Benedictis et al. 2007). Thermophilic keratinases also have potential uses in different applications where keratins should be hydrolyzed, such as leather and detergent industries, textiles (modification of wool fibers), waste bioconversion, medicine, and cosmetics (production of bioactive peptides) (Gupta and Ramnani 2006).

Therefore, the information presented in this work discloses novel and interesting perspectives, demonstrating that microorganisms isolated from geothermal environments actually represent a source of numerous enzymes potentially relevant for the development and/or improvement of biotechnological processes.

\section{Conclusion}

Considering that the hydrolytic enzymes produced by these bacteria are mostly extracellular (shown by the degradation halo around the colonies) which are easier to recover than plant and animal enzymes and that extremozymes have properties which are useful in industrial and environmental processes, the collection presented here may represent a promising source for the development of new processes, highlighting the biotechnological potential of Argentinian volcanic areas.

The enrichment step with chicken feather allowed us to isolate keratinolytic microorganisms that present a degradation rate higher than those keratinolytic microorganisms recovered from NB enrichment. This is the first report on the isolation of strains of B. cytotoxicus and $P$. denditriformis with keratinolytic activity.

\section{Acknowledgments}

Dr Donati would like to especially thank Dr. Ana Monasterio and the authorities of EPROTEN (Ente provincial de termas Neuquén) for allowing access to the Copahue geothermal system and facilitate the collection of the samples.

\section{Funding}

This work was partially supported by grants PICT 2012-0623, PICT 20130630, PICT 2014-1655 (ANPCYT) and PIP 112-201101-00662 (CONICET).

\section{References}

Aanniz T, Ouadghiri M, Melloul M, Swings J, Elfahime E, Ibijbijen J, Ismaili M, Amar M. 2015. Thermophilic bacteria in Moroccan hot springs, salt marshes and desert soils. Braz J Microbiol 46(2):443-453.

Acharya S, Chaudhary A. 2012. Alkaline cellulase produced by a newly isolated thermophilic Aneurinibacillus thermoaerophilus WBS2 from hot spring, India. Afr J Microbiol Res 6:5453-5458.

Adiguzel A, Ozkan H, Baris O, Inan K, Gulluce M, Sahin F. 2009. Identification and characterization of thermophilic bacteria isolated from hot springs in Turkey. J Microbiol Methods 79(3):321-328.

Arya M, Joshi GK, Gupta AK, Kumar A, Raturi A. 2015. Isolation and characterization of thermophilic bacterial strains from Soldhar (Tapovan) hot spring in Central Himalayan Region, India. Ann Microbiol 65 (3):1457-1464.

Baltaci MO, Genc B, Arslan S, Adiguzel G, Adiguzel A. 2017. Isolation and characterization of thermophilic bacteria from geothermal areas in Turkey and preliminary research on biotechnologically important enzyme production. Geomicrobiol J 34(1):53-62.

Bihari Z, Vidéki E, Mihalik A, Szvetnik Z, Szabó M, Kesseru P, Kiss I. 2010. Degradation of native feathers by a novel keratinase-producing, thermophilic Iisolate, Brevibacillus thermoruber T1E. Zeitschrift für Naturforschung C 65(1-2):134-140.

Brandao LR, Libkind D, Vaz ABM, Espìrito Santo LlC, Moline Mn, de Garcia V, van Broock M, Rosa CA. 2011. Yeasts from an oligotrophic lake in Patagonia (Argentina): diversity, distribution and synthesis of 
photoprotective compounds and extracellular enzymes. FEMS Microbiol Ecol 76(1):1-13.

Buzzini P, Branda E, Goretti M, Turchetti B. 2012. Psychrophilic yeasts from worldwide glacial habitats: diversity, adaptation strategies and biotechnological potential. FEMS Microbiol Ecol 82(2):217-241.

Buzzini P, Martini A. 2002. Extracellular enzymatic activity profiles in yeast and yeast-like strains isolated from tropical environments. J Appl Microbiol 93(6):1020-1025.

Carrasco M, Rozas JM, Barahona S, Alcano J, Cifuentes V, Baeza M. 2012. Diversity and extracellular enzymatic activities of yeasts isolated from King George Island, the sub-Antarctic region. BMC Microbiol 12 (251):1-9.

Cavello I, Cavalitto S, Hours R. 2012. Biodegradation of a keratin waste and the concomitant production of detergent stable serine proteases from Paecilomyces lilacinus. Appl Biochem Biotechnol 167(5):945-958.

Chiacchiarini P, Lavalle L, Giaveno A, Donati E. 2010. First assessment of acidophilic microorganisms from geothermal Copahue-Caviahue system. Hydrometallurgy 104(3-4):334-341.

De Benedictis P, Beato MS, Capua I. 2007. Inactivation of avian influenza viruses by chemical agents and physical conditions: A review. Zoonoses Public Health 54(2):51-68.

De Toni CH, Richter MF, Chagas JR, Henriques JA, Termignoni C. 2002. Purification and characterization of an alkaline serine endopeptidase from a feather-degrading Xanthomonas maltophilia strain. Can J Microbiol 48(4):342-348.

Duarte AWF, Dayo-Owoyemi I, Nobre FS, Pagnocca FC, Chaud LCS, Pessoa A, Felipe MGA, Sette LD. 2013. Taxonomic assessment and enzymes production by yeasts isolated from marine and terrestrial Antarctic samples. Extremophiles 17(6):1023-1035.

Fagerlund A, Brillard J, First R, Guinebretiere MH, Granum PE. 2007. Toxin production in a rare and genetically remote cluster of strains of the Bacillus cereus group. BMC Microbiol 7(43):1-8.

Friedrich AB, Antranikian G. 1996. Keratin degradation by Fervidobacterium pennovorans, a novel thermophilic anaerobic species of the order Thermotogales. Appl Environ Microbiol 62(8):2875-2882.

Gill PK, Manhas RK, Singh P. 2006. Comparative analysis of thermostability of extracellular inulinase activity from Aspergillus fumigatus with commercially available (Novozyme) inulinase. Bioresour Technol 97 (2):355-358.

Guinebretiere MH, Auger S, Galleron N, Contzen M, De Sarrau B, De Buyser ML, Lamberet G, Fagerlund A, Granum PE, Lereclus D, De Vos P, Nguyen-The C, Sorokin A. 2013. Bacillus cytotoxicus sp. nov. is a novel thermotolerant species of Bacillus cereus Group occasionally associated with food poisoning. Int J Syst Evol Microbiol 63:31-40.

Guinebretiere MH, Fagerlund A, Granum PE. 2006. Rapid discrimination of cytK-1 and cytK-2 genes in Bacillus cereus strains by a novel duplex PCR system. FEMS Microbiol Lett 259(1):74-80.

Gupta R, Rajput R, Sharma R, Gupta N. 2013a. Biotechnological applications and prospective market of microbial keratinases. Appl Microbiol Biotechnol 97(23):9931-9940.

Gupta R, Ramnani P. 2006. Microbial keratinases and their prospective applications: an overview. Appl Microbiol Biotechnol 70 (1):21-33.

Gupta R, Sharma R, Beg QK. 2013b. Revisiting microbial keratinases: next generation proteases for sustainable biotechnology. Crit Rev Biotechnol 33(2):216-228.

Haki GD, Rakshit SK. 2003. Developments in industrially important thermostable enzymes: a review. Biores Technol 89(1):17-34.

Hamilton LM, Kelly CT, Fogarty WM. 1999. Production and properties of the raw starch-digesting $\alpha$-amylase of Bacillus sp. IMD 435. Process Biochem 35(1-2):27-31.

Harley JP, Prescott LM. 2002. Biochemical activities of bacteria. In: Laboratory Excersices in Microbiology. 5th ed. editor Joanne M Wiley, New York: McGraw-Hill, p125-206.

Ionata E, Canganella F, Bianconi G, Benno Y, Sakamoto M, Capasso A, Rossi M, La Cara F. 2008. A novel keratinase from Clostridium sporogenes bv. pennavorans bv. nov., a thermotolerant organism isolated from solfataric muds. Microbiol Res 163(1):105-112.

Jacques G, Frederic De Lemos E, amotte-Brasseur J, ougnet V, iannotta F, rere JM, evreese B, ranier B. 2000. An additional aromatic interaction improves the thermostability and thermophilicity of a mesophilic family 11 xylanase: Structural basis and molecular study. Prot Sci 9(3):466-475.

Kim JM, Lim WJ, Suh HJ. 2001. Feather-degrading Bacillus species from poultry waste. Process Biochem 37(3):287-291.

Kublanov I, Perevalova A, Slobodkina G, Lebedinsky A, Bidzhieva S, Kolganova T, Kaliberda E, Rumsh L, Haertle T, Bonch-Osmolovskaya E. 2009. Biodiversity of thermophilic prokaryotes with hidrolytic activities in hot springs of Uzon Caldera, Kamchatka (Russia). Appl Environ Microbiol 75(1):286-291.

Lin X, Lee C, Casale E, Shih JCH. 1992. Purification and characterization of a keratinase from a feather degrading Bacillus licheniformis strain. Appl Environ Microbiol 58(10):3271-3275.

Logan N, Allan R. 2008. Aerobic, endospore-forming bacteria from antarctic geothermal soils. In: Dion P, Nautiyal C, editors. Microbiology of Extreme Soils. Berlin/Heidelberg: Springer, p155-175.

Loperena L, Soria V, Varela H, Lupo S, Bergalli A, Guigou M, Pellegrino A, Bernardo A, Calvío A, Rivas F, Batista S. 2012. Extracellular enzymes produced by microorganisms isolated from maritime Antarctica. World J Microbiol Biotechnol 28(5):2249-2256.

Lund T, De Buyser ML, Granum PE. 2000. A new cytotoxin from Bacillus cereus that may cause necrotic enteritis. Mol Microbiol 38(2):254-261.

Margesin R, Jud M, Tscherko D, Schinner F. 2009. Microbial communities and activities in alpine and subalpine soils. FEMS Microbiol Ecol 67 (2):208-218.

Mas GR, Mas LC, Bengochea L. 1996. Hydrothermal, surface alteration in the Copahue geothermal field (Argentina). 21st Workshop Geothermal Reservoir Engineering, p241-246.

Matsui T, Yamada Y, Mitsuya H, Shigeri Y, Yoshida Y, Saito Y, Matsui H, Watanabe K. 2009. Sustainable and practical degradation of intact chicken feathers by cultivating a newly isolated thermophilic Meiothermus ruber H328. Appl Microbiol Biotechnol 82(5):941-950.

Mestre MC, Rosa CA, Safar SVB, Libkind D, Fontenla SB. 2011. Yeast communities associated with the bulk-soil, rhizosphere and ectomycorrhizosphere of a Nothofagus pumilio forest in northwestern Patagonia, Argentina. FEMS Microbiol Ecol 78(3):531-541.

Mohamedin AH. 1999. Isolation, identification and some cultural conditions of a protease-producing thermophilic Streptomyces strain grown on chicken feather as a substrate. Int Biodeterior Biodegrad 43(1-2):13-21.

Nakamura H, Kubota H, Kono T, Isogai A, Onabe F. 2001. Modification of pulp properties by cellulase treatment and application of cellulase to wastepaper deinking and mechanical pulp refining. Pulp and Paper Research Conference, p2-5.

Nam GW, Lee DW, Lee HS, Lee NJ, Kim BC, Choe EA, Hwang JK, Suhartono MT, Pyun YR. 2002. Native feather degradation by Fervidobacterium islandicum $\mathrm{AW}-1$, a newly isolated keratinase-producing thermophilic anaerobe. Arch Microbiol 178(6):538-547.

Park D. 2007. Genomic DNA Isolation From Different Biological Materials. In: Hilario E, Mackay J, editors. Protocols for Nucleic Acid Analysis by Nonradioactive Probes. Totowa, NJ: Humana Press, p3-13.

Pesce AH. 2013. The Domuyo geothermal area, Neuquén, Argentina. GRC Trans 37:309-314.

Plou FJ, Ferrer M, Nuero OM, Calvo MV, Alcalde M, Reyes F, Ballesteros A. 1998. Analysis of Tween 80 as an esterase/lipase substrate for lipolytic activity assay. Biotechnol Techn 12(3):183-186.

Rai SK, Konwarh R, Mukherjee AK. 2009. Purification, characterization and biotechnological application of an alkaline $\beta$-keratinase produced by Bacillus subtilis RM-01 in solid-state fermentation using chickenfeather as substrate. Biochem Eng J 45(3):218-225.

Riessen S, Antranikian G. 2001. Isolation of Thermoanaerobacter keratinophilus sp. nov.; a novel thermophilic, anaerobic bacterium with keratinolytic activity. Extremophiles 5:399-408.

Riffel A, Lucas F, Heeb P, Brandelli A. 2003. Characterization of a new keratinolytic bacterium that completely degrades native feather keratin. Arch Microbiol 179:258-265.

Rohban R, Amoozegar MA, Ventosa A. 2009. Screening and isolation of halophilic bacteria producing extracellular hydrolyses from Howz Soltan Lake, Iran. J Ind Microbiol Biotechnol 36(3):333-340.

Russo G, Libkind D, Sampaio JP, Van Broock MR. 2008. Yeast diversity in the acidic Rio Agrio-Lake Caviahue volcanic environment (Patagonia, Argentina). FEMS Microbiol Ecol 65(3):415-424. 
Sangali S, Brandelli A. 2000. Feather keratin hydrolysis by Vibrio sp. strain kr2. J Appl Microbiol 89:735-743.

Shrinivas D, Naik GR. 2011. Characterization of alkaline thermostable keratinolytic protease from thermoalkalophilic Bacillus halodurans JB 99 exhibiting dehairing activity. Int Biodeterior Biodegrad 65(1):29-35.

Tamura K, Stecher G, Peterson D, Filipski A, Kumar S. 2013. MEGA 6: Molecular evolutionary genetics analysis version 6. Mol Biol Evol 30:2725-2729.

Thebti W, Riahi Y, Gharsalli R, Belhad O. 2016. Screening and characterization of thermo-active enzymes of biotechnological interest produced by thermophilic Bacillus isolated from hot springs in Tunisia. Acta Biochim Polon 63(3):581-587.

Urbieta MS, González Toril E, Giaveno MA, Aguilera Bazán A, Donati E. 2014. Archeal and bacterial diversity in five different hydrothermal ponds in the Copahue region in Argentina. Syst Appl Microbiol 37(6):429-441.

Urbieta MS, González-Toril E, Bazán ÁA, Giaveno MA, Donati E. 2015. Comparison of the microbial communities of hot springs waters and the microbial biofilms in the acidic geothermal area of Copahue (Neu$\mathrm{qu}+{ }^{\circledR} \mathrm{n}$, Argentina). Extremophiles 19(2):437-450.

Vallés JM, Baschini MT, Pettinari GR, García N. 2004. Characterization of muds and waters of the Copahue geothermal field, Neuquen Province,
Patagonia Argentina. Proceedings of the 8th International Congress on Applied Mineralogy, p507-510.

van der Maarel MJEC, van der Veen B, Uitdehaag JCM, Leemhuis H, Dijkhuizen L. 2002. Properties and applications of starch-converting enzymes of the $\alpha$-amylase family. J Biotechnol 94(2):137-155.

Varekamp JC, Ouimette AP, Herman SW, Flynn KS, Bermudez A, Delpino D. 2009. Naturally acid waters from Copahue volcano, Argentina. App Geochem 24(2):208-220.

Verma A, Gupta M, Shirkot P. 2014. Isolation and characterization of thermophilic bacteria in natural hot water springs of Himachal Pradesh (India). The Bioscan 9(3):947-952.

Vieille C, Zeikus GJ. 2001. Hyperthermophilic enzymes: Sources, uses, and molecular mechanisms for thermostability. Microbiol Mol Biol Rev 65(1):1-43.

Williams CM, Richter CS, Mackenzie JM, Shih JC. 1990. Isolation, identification and characterization of a feather-degrading bacterium. Appl Environ Microbiol 56(6):1509-1515.

Zalar P, Gunde-Cimerman N. 2014. Cold-adapted Yeasts in Arctic Habitats. In: Buzzini P, Margesin R, editors. Cold-adapted Yeasts. Biodiversity, Adaptation Estrategies and Biotechnological Significance. Berlin: Springer, p74-90. 